\title{
Situating my positionality as a Black woman with a dis/ability in the provision of equity-focused technical assistance: a personal reflection
}

\author{
Seena M. Skelton
}

\begin{abstract}
In this essay, I reflect on how an equity-focused technical assistance (TA) practitioner who holds intersectional minoritized social identities is in a unique position to introduce tensions in the TA activity system, disrupt marginalizing dominant narratives about difference, and affect educators' development of new ideas about the treatment of difference in schools. To start, I situate myself as the TA provider by focusing specifically on the socio-historical context in which I experienced public K-12 education as a Black, woman with a dis/ability. Next, I outline three reflections related to my experience with the treatment of difference during that time, particularly in terms of race and dis/ability; I consider how my personal history informs my current interactions within the provision of equity-focused TA. I identify three marginalizing impacts resulting from educators' treatment of my and other students' difference; and describe three strategic moves I employ to disrupt and mitigate these impacts. Additionally, I reflect on the question: How might my social identities, intersectional education history, and lived experiences serve as instruments that evoke tensions and affect interactions within the TA activity system?
\end{abstract}

Keywords: Positionality, equity-focused technical assistance, social identities

This is the author's manuscript of the work published in final form as:

Skelton, S. M. (2019). Situating my positionality as a Black woman with a dis/ability in the provision of equity-focused technical assistance: A personal reflection. International Journal of Qualitative Studies in Education, 32(3), 225-242. https://doi.org/10.1080/09518398.2019.1576942 
Situating my positionality as a Black woman with a dis/ability in the provision of equityfocused technical assistance: a personal reflection

Title IV of the Civil Rights Act of 1964 authorized the USDOE to administer funding for Equity Assistance Centers (EACs), originally known as Desegregation Centers. The purpose of these centers is to provide technical assistance (TA) to public school systems for addressing issues occasioned by school desegregation, related to school administration, organization policies, personnel, and community relations (Blake, 1967; U.S. Department of Education, 2017). Among other functions, TA provided by EACs includes making available to school systems, personnel [TA practitioners] specially equipped to advise and assist educators in addressing issues related to school desegregation and ensuring equitable educational opportunities for minoritized youth (Title IV of Civil Rights Act, 1964 sec 403).

It can be argued that the so-called achievement gap (predominantly understood as race and socioeconomic-based gaps in school achievement (Carey, 2013) is the single most prevalent and widely debated educational issue related to school desegregation since the Brown vs. Board of Education rulings. It is a dominant issue in the framing of school reform efforts (Carey, 2013) and TA requests by education practitioners (Midwest and Plains Equity Assistance Center, 2018). The achievement gap discourse, which persistently positions predominantly Black and Latinx students as performing below White students, telegraphs a racist narrative of White supremacy that predates school legal segregation (Carey, 2013; Keisch \& Scott, 2015; Love, 2004). Ironically, many of the actions taken up by school systems in response to inequities in student achievement has led to the (re) segregation of students along racial lines in the form of tracking (Cipriano-Walter, 2015), over-representation of students of color in special education (Artiles \& Kozleski, 2016; Sullivan \& Bal, 2013), under-representation of students in gifted and 
talented classes, (Wright, Ford, \& Young, 2017) and school push out, due to disciplinary suspensions and expulsion (Crenshaw, Ocen, \& Nanda, 2014; Skiba, Artiles, Kozleski, Losen, \& Harry, 2016). Education practitioners seeking ways to address their 'achievement gap problem' rarely recognize the effect of their treatment of student differences in relation to race, sex, dis/ability and other identity markers and the various ways in which school-based oppressions, institutionalized through school structures, curricula, instruction, policies and practices, create barriers to learning for students who are members of minoritized groups. Therefore, students of color, students with dis/abilities and other minoritized youth are defined as the problem themselves, rather than as victims of institutional racism, sexism, ableism and other systemic oppressions. This in turn prompts school systems to seek out school reform solutions to fix these students through remediation and intervention (Artiles \& Kozleski, 2016; Chambers, 2009; Ferri \& Connor, 2010; Ladson-Billings, 2006; Valencia, 2015).

In this essay, I reflect on how the presence of a TA practitioner who possesses intersectional minoritized social identities is in a unique position to introduce tension in the TA activity system, disrupt marginalizing dominant narratives about difference, and affect educators' development of inclusive ideas about difference (Engeström, 2011; Tan \& Thorius, 2018). As a Black woman with a dis/ability, I discuss the socio-historical context in which I experienced public K-12 education to consider how these experiences inform my current interactions within the TA experience. Additionally, I reflect on the question - How might my social identities, intersectional education history, and lived experiences serve as instruments of tensions, affecting interactions within the TA activity system? I outline three conclusions related to my experience with the treatment of difference in education, particularly related to race and dis/ability as a youth; and consider how my personal history informs my current practice as a TA practitioner. I 
identify three marginalizing impacts I observe during the provision of TA, resulting from educators' treatment of mine and others' difference; and describe three situated strategic moves I employ to disrupt and mitigate these impacts.

\section{A socio-cultural theoretical framework for equity-focused technical assistance}

Trohanis (2014) describes TA as 'collaborative and coordinated approach to facilitating change, building the capacity of both organizations and individuals developing improved ways of doing things and ultimately achieving agreed-upon outcomes' (p. 1). TA is typically characterized by an almost exclusive focus on improving operational or technical aspects of school systems such as the adoption and implementation of a particular program (Kozelski \& Artiles, 2012). However, this focus on technical solutions without examining contextual factors, (e.g. people's beliefs, traditions, routines, policy and norms), as well as a critical investigation on how these aspects contribute to patterns of practice that benefit or marginalize students based on their social identities, does little to redress systemic inequities necessary for bringing about transformational change towards educational equity (Mulligan \& Kozelski, 2009). 'Outcomes that benefit the most oppressed groups of students can become tangential to technical improvements to the system' (Kozelski \& Artiles, 2012, p. 5). Integral to equity-focused TA is an understanding that transformative work includes the implementation of co-constructed solutions situated within critically examined contexts (Kozleski \& Artiles, 2012; Thorius, 2016; Waitoller \& Kozleski, 2013).

Equity-focused TA occurs within socio-cultural activity systems (Thorius, 2016). Social-cultural frameworks for understanding human activity draw from Vygotsky's (1978) concept of cultural mediation - and relatedly, the production of knowledge within a TA relationship would be understood as occurring through socially-mediated collective human activity that is culturally 
and historically situated (Cole \& Wertsch, 1996). It is within this complex mediated experience that new understandings or knowledges are co-constructed in effort to realize a specific goal (Engeström, 1999). In equity-focused TA operating from this frame, the TA practitioner operates less as a purveyor of specialized information, whose role is to transmit information or to engage professional development activities in order to facilitate behavior and systems change, but rather a social partner within an activity system (the TA experience) which consists of interactions with education practitioners who bring their own cultural histories and motivations (e.g. community concerns, political forces, policy mandates) for engaging (Skelton et al., 2017; Thorius, 2016; Thorius, Maxcy, \& Nguyen, 2015; Thorius, Skelton, \& Warren, 2016). Integral in the process is the involvement of tools, artifacts, information or mental models and frameworks introduced into the activity system by the TA practitioner and used to mediate new understanding (Kozleski \& Artiles, 2012; Kozleski \& Waitoller, 2010; Thorius et al., 2015; Waitoller \& Kozleski, 2013). It is the tension evoked from the artifacts or tools introduced to the TA experience that contributes to new meaning-making and the co-construction of new solutions through an expanded object of activity (Thorius, 2016): what Tan \& Thorius call equity expansive TA (2018).

Equity-focused TA shifts conversations and efforts related to educational outcomes from closing achievement gaps to improving equitable access to quality learning opportunities for each and every student. This requires educators to examine how their own beliefs, discourse, policies, and interactions create the conditions in which students learn and are connected with positive and negative outcomes (Chen et al., 2014; Kozleski \& Waitoller, 2010; Sullivan, Artiles, \& Hernandez-Saca, 2015). For many educators, acknowledging how they are complicit in (re) producing racist, sexist, ableist, and other oppressive societal systems in schools is a radical departure from their typical understanding and discourse about achievement gaps. At best this 
can cause great consternation among educators engaging in equity-focused TA, and at the extreme, outright rejection of this (re)frame and resistance to the continuation of the TA relationship (Great Lakes Equity Center, 2012). TA practitioners bearing the brunt of the reaction from educators engaged in the TA activity, must negotiate through the White fragility (DiAngelo, 2011) and various forms of denial that are inevitable when confronting policies and actions which signals their subscription to the dominant ideologies that position minoritized youth as inferior compared to their White, non-disabled, cisgender, middle class peers (Zardoya, 2017). Effectively supporting school systems toward equity-focused transformative change requires attention to the beliefs, dispositions, behaviors and competencies of individuals within the systems, as well as the social systems and structures in which they exist (Gass, 2010).

\section{The TA practitioner as a mediating tool}

As stated above, a crucial aspect of equity-focused TA is the TA practitioner's introduction of artifacts or tools into the TA activity system to purposely cause disruption to status quo actions that (re) inscribe marginalizing paradigms in the school systems (Thorius, 2016). It is the tension caused by interactions with these tools or artifacts that promotes new understanding (Engeström, 2011) among TA participants. Additionally, TA practitioners' knowledge, interaction styles, moves, language choices, stories, and embodied identities may also challenge and disrupt educators' beliefs and mental models that contribute to systemic oppressions (Thorius et al., 2015; Thorius et al., 2016). In this sense, the TA practitioner's personal characteristics and negotiated positionality are tools affecting the TA objective. Accordingly, one may consider how TA practitioners' actual presence, including their embodied identities can also serve as powerful mediating tools toward the expanding object of TA.

\section{Reflecting on my social identities}


In the following sections, I discuss how my social identities, cultural histories, and beliefs contribute to interaction patterns that influence conditions within the TA relationship and are mediating artifacts in the provision of equity-focused TA. I am a Black, cisgender woman with a dis/ability. I use dis/ability with a slash to signify dis/ability as a product of cultural, political, and economic practices (Annamma, Connor, \& Ferri, 2016; Davis, 1995; Waitoller \& Thorius, 2016). The slash does not denote a denial of biological and psychological impairments, but to emphasize that the meaning attributed with these conditions are a result of human activities informed by societal norms and political action (Davis, 2013; Waitoller \& Thorius, 2016).

I was born in the fall of 1970 in Detroit, Michigan. I am the only girl and middle sibling in a family of three children born to a Black mother and father also born in Detroit. As a child, I was the only member of my family with a dis/ability. I grew up in a middle-class family; my mother worked as secretary and my father held various jobs, including working at the Ford auto plant. During my elementary school years, my mother went back to school earning her Bachelor's and later her Master's degrees in clinical social work, and after working as a family therapist in two community-based mental health agencies, opened her own private practice. I was born premature, weighing two pounds, seven ounces at birth. I have a rare genetic disorder, which causes me to be short in physical stature, to have muscle contractures - the tightening or shortening of muscles in my elbows and knees - and scoliosis. Due to the severity of the muscle contractures in my left leg, it became more difficult for me to walk as I grew. At the age of eight, I became an above-the-knee amputee and learned to walk with a prosthetic leg. Because of these orthopedic and health differences, and from the perspective of both the medical - model that locates disability within the individual and views physical, sensory, learning or emotional impairments as deficits to be diagnosed, treated and/or cured and the social model of disability - 
that views dis/ability as socially constructed in response to society norms (LoBianco \& Sheppard-Jones, 2007) I was labeled as a child with a disability, first by the medical system and then the school system. Whereas at first the disability identity was placed upon me by the medical and education systems, I reject the conceptualization that dis/ability is inextricably linked to pathology (Blustein, 2012), and now claim dis/ability as one of my many social identities. As early context for my current work as an equity-oriented TA provider, I share how the intersecting identities of race and dis/ability affected my public school experiences and informed my current perspectives related to the treatment of difference in schools.

\section{My schooling experience}

By the 1970s, due to the relocation of millions of African Americans from southern cities to the north, midwest and west, White flight, redlining, and violence targeting African Americans seeking to move to suburban areas, Detroit became one of the most segregated cities in the United States (Darden, Rahbar, Jezierski, Li, \& Velie, 2010). In the mid-seventies, more than two-thirds of students in city schools were Black (Meinke, 2011). During this time many Black parents complained of unequal educational opportunities offered in majority Black schools when compared to majority White schools, citing outdated textbooks, large class sizes; and dilapidated school buildings (Meinke, 2011). Led by Verda Bradley, a group of Black parents and the NAACP filed a case in the Federal District Court against the state governor William Milliken, charging that official policies had segregated Detroit schools (Bradley \& Fisher, 1998). After several state-level rulings and appeals, Milliken vs. Bradley was heard by the U.S. Supreme Court.

In 1974, the Supreme Court reversed and remanded the decisions of the lower courts by ruling that 'school systems were not responsible for desegregation across district lines unless it could be 
shown that they had deliberately engaged in a policy of segregation; and that desegregation did not require any particular racial balance in each 'school, grade or classroom' (Milliken vs. Bradley, 1974, p. 418). Over the following decades, schools in the metropolitan Detroit area became more segregated, with city schools attended mostly by Black and Latinx students, with surrounding suburban schools mostly attended by White students (Sedler, 1987).

In 1975, Public Law 94-142, the Education of All Handicapped Children Act, now known as the Individuals with Disabilities Education Act (IDEA), was enacted and mandated that children with disabilities be provided a free and appropriate public education (FAPE) designed to meet their unique needs in the least restrictive environment (LRE). 'With no specific definition of LRE stated in the legislation, school systems created a continuum of alternative placement options making LRE not one particular setting (i.e. general education classroom)' (Kavale \& Forness, 2000, p. 3). Without a definition of LRE, a primary focus for serving students receiving special education has been on the physical location rather than the quality of instruction provided (Artiles \& Kozleski, 2016). Both Black and Latinx students have been and continue to be overrepresented in more restrictive educational environments and under-represented in less restrictive settings when compared to White peers with the same disability (Fierros \& Conroy, 2002; Skiba et al., 2016) especially in more subjective categories such as learning disabilities or speech and language impairment (Artiles, 2011; Losen \& Welner, 2001; Russo \& Ford, 2015; Ford \& Harmon, 2001). In spite of the Brown decision, institutional structures and the enactment of state and federal education policies converged with every day educational practices to keep students of color with and without dis/abilities segregated from their White, non-disabled peers (Losen \& Welner, 2001). It is against this backdrop that as a 5-year old, I entered kindergarten in the city's public school system fall 1975. 


\section{My introduction to the treatment of difference in schools}

There is a 4-year difference between my older brother and me. He was identified as gifted in the second grade, wholly by accident. My brother began reading at a very young age and by the end of the first grade, he was reading chapter books from my parents' bookshelf. He attended the neighborhood public elementary school, located approximately two blocks from our home. Early in the school semester, my brother's second grade teacher reported to my mother that he appeared to be disengaged from classroom instruction; and complained that instead of reading the class textbooks, she would catch him with books from the library. My mother recalls telling the teacher that my brother had read all of his textbooks in the first weeks of school (S. YoppSkelton, personal communication, 17 December 2018). She went on to share that he was an avid reader, and a very curious and imaginative child. Not to be believed as a credible informant of her own child's capabilities, my brother was referred for psycho-educational testing by his classroom teacher, for a suspected learning disability. The assessment revealed an IQ score of 160, with no significant IQ and achievement discrepancy: the traditional method used to determine a learning disability and eligibility for special education services (Algozzine, Forgnone, Mercer, \& Trifiletti, 1979). 'Despite inconsistency and a lack of consensus [in defining giftedness], most definitions of giftedness are IQ-based and test-driven (Ford \& Grantham, 2003, p. 218);' therefore instead of a disability label and placement in special education, my brother was identified as gifted. This identification brought about a different set of challenges for the school and thus my parents. Although there was a clear roadmap for what to do with Black children who were determined to have a learning disability, there was no place in our neighborhood public school for educating 'gifted' Black second graders at the time. It was up to my parents to find another school more suited to my brother's learning differences and they 
enrolled my brother in a suburban private school 20 miles north of the city. The racial demographics of the suburban area was approximately 95\% White (U.S. Census Bureau, 1970).

Two years later, as I was approaching Kindergarten age, my parents began thinking about my schooling. Because of my orthopedic and health differences, my parents were counseled by doctors and other parents of young children with dis/abilities to search for an alternative school from my neighborhood school (S. Yopp-Skelton, personal communication, 10 December 2018). The repeated message my parents received was that the school in my neighborhood could not provide the 'right' environment for my specific 'needs.' Again my parents were on a quest to find a school that would be responsive to their child's unique characteristics. Having been down this road once already with their oldest child, my parents were all too familiar with the battery of psychoeducational assessments and procedures I would receive.

Upon entering Kindergarten, I was identified as and received special education services for the state of Michigan's special education category Physically or Otherwise Health Impaired (POHI). POHI was defined as a physical or other health impairment, which adversely affects the student's educational performance (Michigan State Board of Education Revised Administrative Rules for Special Education and Rules for School Social Worker and School Psychological Services, 1987). As with the majority of students with dis/abilities at the time, I was enrolled in a segregated elementary school in Kindergarten specifically for students identified as POHI. The school was not located in my neighborhood but instead approximately six miles from my home. The school building was one floor, with handrails attached to the walls to assist in walking, and extra wide hallways to accommodate multiple wheelchairs going down the hallway simultaneously. The school was bright and colorful; there was a gymnasium and a library. 
Weekly I went to physical and occupational therapy in a room down the hall from my classroom. I liked school, I was a good student, enjoyed learning and performed well.

When I was in the first grade, I attended a parent-teacher conference at my brother's school with my parents. I recall marveling at how different his school and classrooms were from mine. There were no desks situated in rows; instead students sat around tables, or in upholstered chairs and small sofas. Each classroom had its own library, in addition to the main library at the center of the campus. The teachers used project-based learning and Montessori methods as primary instructional approaches, and although I did not have the language at the time to describe the pedagogical approaches, I knew that the way I was being taught in my school (primarily with worksheets and workbooks) was qualitatively different than how my brother experienced learning in this suburban private school. I also noticed that almost all of the students attending his school were White. The school was on a campus where classrooms were located in several small buildings throughout the school grounds. Children traveled across grass courtyards and stairs to access various buildings. I found his school exciting and wanted this kind of experience too. I told my parents that I wanted to attend school with my brother. Very pleased with the quality of education my brother was experiencing, my parents inquired about my enrollment in the school. This would not be possible; my parents were informed by the school administration the school would not be able to provide the special education services I needed and because of the size and terrain of the campus, would be too difficult for me to navigate (S. Yopp-Skelton, personal communication, 17 December 2017).

In the sixth grade, I transitioned from elementary school to middle school. This was the first time I attended school with non-disabled students. However, I continued to experience segregated schooling in self-contained classrooms until age 12. In seventh grade, I was mainstreamed into 
general education classrooms along with classmates also identified as POHI. Students identified with learning disabilities, intellectual disabilities, and emotional disturbances in the same school primarily continued to receive their education in self-contained classrooms. I went on to attend high school in the city's public school system, attending class with non-disabled students for all of my high school subjects in general education classrooms. However, because district policy at the time was to bus students with various dis/ability labels to designated schools within the district, I never attended my neighborhood public school. Throughout my elementary and secondary education experiences, how educators constructed and treated my differences and those of others remained relatively consistent and led me to three key conclusions: (1) schools were White, non-disabled spaces; (2) educators held low expectations for students of color and students with dis/abilities; (3) and intersecting identities were not considered.

\section{Schools were White, non-disabled spaces}

Although I attended elementary and secondary schools in which $100 \%$ of the students were students of color and many of the educators, staff members and administrators were also people of color, both the formal and hidden curricula normalized instructional spaces that privileged Whiteness and perpetuated ableist, and racist ideas of White supremacy (Allen, 1999; Morrison, Annamma, \& Jackson, 2017). There were few options for accelerated learning opportunities for schools in the city, predominantly attended by students of color. Gifted education was for White students and suburban schools.

'Majority White schools were better resourced and had lower student - teacher ratio than majority Black schools' (Boozer et al., 1992, p. 286). 'White students had exposure to resources and new technologies (e.g. computers), and were instructed with the aid of computers and other 
current technologies, at a much earlier stage of their educational career than were students of color attending city schools' (Boozer et al., 1992, p. 295).

Students with dis/abilities were hidden and kept separate from their non-disabled peers. Whether in separate buildings, annexed structures or self-contained classrooms, students with disabilities and non-disabled students existed as if in parallel universes, infrequently interacting with one another. On occasions, students with dis/abilities would participate alongside their non-disabled peers in the same classrooms but only if their differences were not too pronounced. Approximating normalcy was expected (Davis, 1995). Any need for individualization in instruction or the instructional environment had to be met in the special education resource room (Dudley-Marling \& Burns, 2014). The response to difference was to separate from the typical and to remediate towards the normal. Schools were not places where differences were appreciated, reflected in the formal or informal curriculum and normalized as part of human existence. Instead difference was treated as a problem to be solved or a disorder to cure through assimilation; and if assimilation was not possible exclusion.

\section{Deficit-thinking and low expectations for minoritized students limited access to opportunities}

The intersection of race and dis/ability surfaced in my schooling experiences in overt and subtle ways. From the time I was mainstreamed into general education classrooms, I became aware that educators held lower expectations for me based on my dis/ability specifically, and race, generally. 'Deficit thinking exists when educators hold negative, stereotypic, and counterproductive views about diverse students and lower their expectations of these students accordingly' (Ford \& Grantham, 2003, p. 217). The first quarter in my seventh grade year, after I was mainstreamed into general education classrooms, I received a failing grade on my report 
card in English Language Arts class (E/LA). Prior to this, I had always performed well academically, and never received a failing grade in any subject. My E/LA teacher was an African American woman and had a reputation for being strict and no-nonsense. However, students tended to do well in her class. During a parent-teacher conference with my E/LA teacher, my mother recalls the teacher saying to her that handicapped students couldn't be expected to perform as well as other children and that she believed handicapped children really did not belong in regular classes. Immediately following this conversation, my mother requested that I be transferred into another classroom, stating that she believed the teacher's biased attitude towards students with dis/abilities negatively affected my learning experience and performance. I was transferred into a different general education seventh grade homeroom and E/LA class. After my transfer, my academic performance returned to typical levels for me prior to mainstreaming, receiving high marks on all assignments. When I entered high school, I participated in an Individualized Education Program (IEP) meeting for the first time. IEP meetings include a representative of the local educational agency qualified to provide, or supervise the provision of special education services and can involve student's teacher (s), parents or guardians, and, whenever appropriate, students (Education for All Handicapped Children Act of 1975; Individuals with Disabilities Education Act, 1997). The IEP itself is a document that describes the specially designed instruction for students with educational disabilities and includes a statement of the student's present levels of educational performance, annual goals, instructional objectives, educational services and a description of the extent to which the student will participate in general educational programs (Education for All Handicapped Children Act of 1975; Individuals with Disabilities Education Act, 1997; Individuals with Disabilities Education Act, 2004). I participated in this meeting with my mother, and representing the local education 
agency was the high school special education teacher for POHI students. I recall it being a pleasant meeting, and I felt empowered by the opportunity to provide input into my IEP. Both my mother and I discussed my plans to attend college or university after completing high school. Receiving a college degree was important in my family culture. My siblings and I experienced my mother returning to school during our elementary school years to further her own education. My older brother, whom I admire a great deal, during this time, was entering his freshman year in undergraduate school, attending a private liberal arts college in northern Michigan. It was expected that I too would attend a college or university away from my home, after completing high school. However, early on it was very clear to me that my special education teacher and guidance counselor believed my educational aspirations too lofty. When I received my class schedule on the first day of high school, instead of college preparatory classes, my schedule included vocational classes and study hall in the special education resource room. During this time, the majority of the special education students in Michigan's public schools were enrolled in vocational education programs and significantly fewer students were enrolled college preparatory programs (Manzitti, Boratynski, \& Rader, 1976). It appeared that the policy-aspractice (Sutton \& Levinson, 2001) was to enroll students with dis/abilities in vocational programs and in my particular case, regardless of the student's present level of performance, special education goals, objectives, or needed services. I knew my class schedule would not provide the requisite course work I needed for college; and at the age of fourteen began advocating for access to more rigorous learning opportunities. Although I would have the support of some teachers who established rigorous standards and demonstrated an expectation that I would meet them, such educators were far and few in between. I continued to battle deficit thinking and resist lower expectations from many educators throughout my high school 
experience and in some instances regardless of my persistence, was denied information about and access to specific advanced-level educational experiences.

\section{Intersecting identities were not considered}

Students were either disabled or non-disabled, gifted or typical learners, White or non-White. De facto racial segregation schools maintained disparities in the quality of educational opportunities between majority White schools and majority schools of color (Boozer et al., 1992; Sedler, 1987). For some parents of color, elite suburban private schools provided an option for higher quality educational opportunities for their children. Private foundations offered tuition scholarships to some students of color, affording them an opportunity to attend private schools where tuition fees would otherwise have been prohibitive, in efforts to increase diversity among the student body (Yun \& Reardon in Scott, 2005). However, school structures and educator perceptions proved to be barriers as well for students with dis/abilities (Karnes, Shaunessy, \& Bisland, 2004). The opportunities some students of color may have had to access higher quality educational opportunities by attending elite private schools, were denied to students of color with dis/abilities.

Students of color with dis/abilities are caught between the overlapping oppressions of racial segregation and ability segregation. Civil rights laws prohibited de jure segregation based on race, but federal and state special education policies and practices reproduced segregated learning environments for students with dis/abilities who are disproportionality students of color (Donovan \& Cross, 2002; Losen \& Welner, 2001).

Reactions to differences among students manifest themselves in various ways, and they exert a powerful influence in educational settings (Ford \& Grantham, 2003, p. 218). I had received the 
message very early on both in explicit and implicit ways that schools dealt with difference by labeling, categorizing and segregating students - thus imposing structural and psychological limitations on what students can achieve.

My post-secondary education reality reflected a more integrated experience. I attended public universities for undergraduate and graduate schools, of my choosing and dis/ability services were provided (e.g. transportation services) as needed. There were no self-contained classrooms, resource rooms or any other configuration of segregated schooling. The institutions, I attended were mid-sized, public universities where there was representation of students of color learning alongside White students. Although the frequency of ableist and racist microaggressions I experienced decreased in undergraduate and graduate schools, implications of structural racism and ableism were ever present, particularly signaled by a lack of representation of students of color with dis/abilities in the universities I attended (Annamma et al., 2016). I graduated school with advanced degrees in education and school psychology and for the first 4 years of my career worked as a school psychologist, affording me yet another perspective of the treatment of difference in schools.

\section{Strategic moves to disrupt the marginalizing impacts of educators' treatment of difference}

Students across the United States bring to school their multi-dimensional and intersectional identities (Hernández-Saca, 2017). The intersectional experiences of my own educational history as a youth enable me to have a particular perspective of the treatment of difference in PK-12 schools. Together with my career as a school psychologist I have insider knowledge of how public and educational policies are appropriated and enacted locally in schools. As a Black woman with a dis/ability, I am personally aware of the intended and unintended consequences of being a student of color with a dis/ability, such as segregated learning experiences, lower 
expectations and stigma (Artiles, 2013; Donovan \& Cross, 2002; Huber, Artiles, \& HernándezSaca, 2012).

Typically the impetus for TA for systemic school improvement is to help the school leaders address achievement disparities between and among minoritized student groups and their White, non-disabled peers. Frequently the students of concern are students with whom I share similar characteristics and lived school experiences. As a TA practitioner who embodies intersecting minoritized identities, I often have more in common with the students who are seen as the problem than the educators who have requested support, most of whom are White and nondisabled. I am acutely aware of and sensitive to the forms of marginalization of minoritized students that is produced through school curricula and textbooks, instruction and other federal, state and local school policies. As such, I constantly navigate an insider-outsider perspective; and my positionality is (re)negotiated in relation to the educators with whom I work.

In my TA practitioner role I regularly experience micro-aggressions related to race and dis/ability from the educators participating in the TA experience even as these same educators espouse a commitment to redressing educational inequities in their schools. For example, during a session about promoting inclusive practices with a group of special education teachers, when I greeted the educator with whom I was paired, upon hearing my role (TA provider) and title (director), the educator replied 'Oh... (in a surprised tone) well, good for you!' In other instances, micro-aggressions manifest in different ways such as when educators approach a White or non-disabled subordinate staff member on my team with questions rather than seeking support from me, signaling their questioning of my expertise or the legitimacy of my role.

I also experience being positioned as someone with intimate knowledge and understanding of the kinds barriers many of the students who are the target of school improvement efforts address. My 
educational credentials and personal experiences with ableism and racism afford me credibility to raise equity issues with educators. In these and other instances, I leverage my insider knowledge related to my personal and professional experiences with schools' treatment of difference, to mediate the TA experience. This duality of being perceived simultaneously competent and incompetent, by the nature of my educational attainment, personal history, and demonstrated expertise and because of deep-seated racist and ableist ideologies, respectively, creates perceivable tension and dissonance among the education practitioners engaged in the TA relationship. As a result, I have come to view my differences as important factors in disrupting status quo ideologies about difference in school.

Recognizing the impact of my embodied identities in the TA experience, I have strategically used my identities and related lived experiences in what can be described as intentional moves to disrupt espoused beliefs related to how educators treat difference, specifically related to race and dis/ability. The following capture what I perceive are three marginalizing impacts of educators' treatment of difference I experience as a TA practitioner, which connect to my own educational history as a Black woman with a dis/ability, along with equity-expansive (Tan \& Thorius, 2018) (re)mediating (i.e. countering) moves I use to disrupt these impacts.

\section{Marginalizing impact \#1: identity erasure}

Educators are initially reluctant to acknowledge my dis/ability or race; seemingly going out of their way to ignore my differences while at the same time noticeably staring at them. All too frequently educators make comments analogous to ' ...not seeing race ... dis/ability ... and just seeing students.' This type of racial or [identity] erasure (McKenzie \& Scheurich, 2004) devalues and invalidates students' racialized or other minoritized identities experiences (Artiles \& Kozleski, 2016; Bonilla-Silva, 2003; Ladson-Billing, 1998). 
When it comes to dis/abilities, some educators and even fellow (non-disabled) TA practitioners tend to use euphemism such as 'special needs' to describe dis/ability. This avoidance of the term dis/ability contributes to the erasure of disabled individuals and their lived experiences (McRuer, 2006). Additionally, substituting the words dis/ability and disabled with terms like special needs perpetuate the stigma of dis/ability, reinforcing the belief that dis/ability is negative and is marked by deficits (Myer, 2018).

The experience of educators evading race and dis/ability as I work alongside them in the provision of TA, bring to mind my own personal history and trigger emotions about (HernándezSaca, 2017) and memories of my schooling and in particular, of schools as White, non-disabled spaces.

\section{(Re)Mediating move \#1: naming and claiming my identities out loud}

I have found that speaking openly about my racial and dis/ability identities within the provision of TA provides a model for educators to talk about their own recognition of difference, not only as it relates to their students but also their own identities. A specific move that I engage early on in the TA relationship is to introduce myself by situating my identities in the telling of my own equity story. Although it is typical for TA practitioners to share information about themselves at the start of a TA relationship, most other TA providers outside our organization usually limit their comments to professional background and work experience. Within my center, the sharing of professional background appear to serve a different purpose for my White, non-dis/abled colleagues than for me. For them, it facilitates rapport building, breaks the ice, and maybe establishes creditability. For me, this introduction is a strategic move to simultaneously establish my creditability (disrupting conscious or unconscious presumption of my incompetence, based on my race and dis/ability (Annamma et al., 2016), claim my racial, gender, and dis/ability 
identities (acknowledging a sense of pride, membership and responsibility to the Black, women, and dis/ability communities to which I belong); and model the importance of a critical appreciation of difference (acknowledging the power dynamics at play in schools that marginalize and privilege people based on those differences). I have observed that by stating outloud my race and dis/ability in particular, educators seem to relax, appreciating that they do not have to keep up the pretense of not noticing my differences. In addition, in naming my identities, I demonstrate a valuing of difference and thus, educators have been moved to confront their own identity-neutral responses toward students of color and students with disabilities.

\section{Marginalizing impact \#2 privileged identities}

Equity-focused TA engages educators' critical consciousness - the examination of how social forces exert power and afford privileges that systematically advantage individuals holding dominant social identities (White, non-disabled, male, cisgender etc.), while at the same time disadvantage individuals with non-dominant social identities (people of color, dis/abled, female, gender non-confirming etc.) (Radd \& Kramer, 2013). Such examination is central to redressing educational inequities (Duncan-Andrade, 2007). In my experience, educators are receptive to discussing the dynamics of difference, privilege and power (Johnson, 2001) at a conceptual level, however, perceiving how power dynamics actually operate in practice, and how they themselves can be complicit, is more elusive. Racism and ableism are normalized features of U.S. society and institutions, including schooling (Annamma et al., 2016; Bonilla-Silva, 2003; Delgado \& Stefancic, 2000; Watts \& Erevelles, 2004); and as such, ingrained in educators' discourse and practice (Ladson-Billings, 1998). The White, non-disabled educators with whom I work, failing to recognize their own privilege, are often challenged to perceive how their race and dis/abilityneutral practices (re) produce the same systems of oppressions they are attempting to redress. For 
example, I worked with a district engaging in efforts to address discriminatory practices occurring in the district, in response to a complaint file by parents of a Black student with the Office for Civil Rights (OCR). The district was required to form a cross-stakeholder school climate task force, including district staff, parents, students, and community members, to act as an advisory group to the district leadership. The administrator leading the group (a non-disabled White male) employed the same color and dis/ability neutral strategy in selecting task force members that he always used for creating district committees - a nomination process, whereby school principals are asked to nominate staff members, students and family members to be invited to join the task force. From the perspective of the administrator, this was the most efficient way to identify members for the task force. The nomination method resulted in a task force consisting of all White adults and mostly White students (one student identified as biracial).

The district administrator did not recognize how, in this district that was 95\% White, White parents, students, and community members were privileged in terms of having access to and positive relationships with school principals. The administrator neglected to acknowledge how practices that were clearly marginalizing to students of color in the district (hence the OCR findings of racial discrimination), were also operating in ways that excluded parents and other community members of color. The failure to specifically employ strategies that disrupted barriers of access for communities of color in the district when seeking to configure the task force, led to a task force that lacked the very perspectives and voices necessary to surface oppressions experienced by students of color in the district, and to effectively lead to the generation of equity-focused solutions. The fact that the administrator did not readily recognize this as a 
problem again signaled for me the persistent signal that schools are White, non-disabled spaces that I experienced in my youth.

\section{(Re) Mediating move \#2: leveraging my identities to illuminate incongruence between educators' rhetoric of equity and their marginalizing practices}

I leverage my own identities to call out racist, sexist or ableist discourse, decisions and actions, which may have gone unnoticed and/or unchecked. I am often surfacing within the provision of TA, that the process of achieving a so-called equity goal is as important as the equity goal itself. In the example above, during the first meeting, sitting in the group of task force members and being the only adult of color in the room, I illustrated that fact by saying '... when I look around at who is in the room, I notice that I am the only adult of color, specifically the only Black person in the room; and I am not a member of your district.' I reminded the group that the impetus for the development of the task force was to address OCR's finding of evidence of racial discrimination in the district. A fact that was mentioned but quickly glossed over by the administrator when explaining the purpose of the task force. Instead he emphasized a focus on creating welcoming environments where all students are appreciated as individuals. The administrator again taking a color neutral stance, erased race as an important detail for creating the task force, thus failing to take account of or accountability for the racism experienced by students. I posed the question. 'I wonder how without the perspectives and voices of students and community members of color represented on the task force, will the group really know and understand what students of color are experiencing?' This was initially met with uncomfortable silence and stares. The calling out of race, particularly by a person of color was something that district staff and community members were not accustomed to. My physical presence and 'voice' compelled task force members to grapple with their own racial discomfort (DiAngelo, 2011). By 
calling out my own Blackness and speaking up about the lack of representation of people of color from their own community on the task force, I illuminated the exclusion of people of color on the task force as well as in other school spaces.

\section{Marginalizing impact \#3: deficit thinking}

It is typical for the education practitioners with whom I work in TA provision to advocate for inclusion and engage in equality rhetoric. So, it is startling to these practitioners when I have spoken overtly about incidents of microaggressions that I have experienced in the course of my work with them. Fergus (2017) stated that educators hold bias-based beliefs that reinforce deficit thinking and operate to sustain systems of oppression based on minoritized identities. This deficit ideology is often used in the field of education and in schools to explain academic performance as a result of deficiencies within a student or student group and their families/communities (Valencia, 1997 in Fergus, 2017). In the course of engaging in equity-focused TA, I have been involved in conversations among educators that centers the under-performance of students of color and students with dis/abilities, usually beginning with the seemingly obligatory showing of the state test data, followed by a discussion about the persistent so-called achievement gaps between students of color and their White non-disabled peers. The conversation inevitably disintegrates into conversations peppered with contempt for the families and communities to which these students belong and pity for the students (Paris \& Alim, 2014). The sentiments undergirding these discussions discount the presence of systemic inequities as a result of racebased processes, practices, and policies (Fergus, 2017).

\section{(Re)Mediating move \#3: personal story-telling}


As a youth, I personally contended with educators' deficit-thinking and lower expectations for minoritized students, as well as the limited learning opportunities afforded to them. Therefore my understanding of what it takes for students and their families with minoritized identities to navigate this terrain is more than theoretical. I am able to tell my stories of confronting deficit thinking as a youth and the impact it had on me. In doing this I can interrupt a discourse associated individualism and meritocracy that maintains, each person is a unique individual and that our group memberships, such as race, class, or gender, are not important or relevant to our opportunities (Flax, 1999 in DiAngelo, 2010). I can situate student achievement in the opportunities or lack of opportunities available in systems that are oppressive for minoritized students contributing to their outcomes.

For example, I share that although I had a 3.5 grade point average in all college preparatory class in high school, I was discouraged from planning to attend a university by my high school guidance counselor and provided leaflets for community college instead. I tell stories of how information about school-organized visits to nearby universities was not provided to students in special education. I share that later as an adult, I learned that during the time I was in high school there was a state-wide policy of special education teachers tracking students on IEPs into vocational training regardless of the students' IEP goals or academic performance was (Manzitti, Boratynski, \& Rader, 1976). I share that while neighboring suburban schools where mostly White students attended provided afterschool ACT and SAT practice sessions, my school where mostly Black students were enrolled did not provide these same opportunities, demonstrating a belief that Black students were not expected to take college entrance exams. When I tell stories of my lived experiences as a youth, I am able to personalize as well as deconstruct for educators how deficit ideology contributed to a narrative that Black students and students with dis/abilities 
didn't attend college and reinforced practices and policies that decreased opportunities affecting student achievement.

As a Black woman, with a dis/ability, I bring a unique history, perspective, and voice into a TA activity system. I embody the social identities that educators' grapple with in the process transformative equity work. I have been able to identify and surface racist and ableist behaviors demonstrated by the educators in ways that invite self-examination of their individual beliefs and perceptions about race, dis/ability, gender and other identities.

\section{Implications}

One's positionality can be both a hindrance and an advantage within the provision the TA. In this self-reflection, I have examined how I leverage my positionality to serve as a tool for stimulating systemic change towards educational equity. The intentional use of one's social identities and associated histories has several implications for TA research and theory, as well as systemic change work.

\section{Research and theory in technical assistance}

The provision of TA has been one of the most relied upon strategies for advancing educational reform for decades, however theory and research related to implementation is just emerging (Kozleski \& Artiles, 2012; Kozleski \& Thorius, 2014; Thorius, 2016; Thorius \& Simon, 2014). The critical nature of equity-focused TA would suggest TA practitioners' awareness of how their positionality influences TA interactions and outcomes is an important aspect of effective implementation. I would recommend that continued theorizing related to equity-focused TA include the role TA practitioners' social identities play in the TA activity system. In this paper, based on my personal experiences I have noted perceived shifts influenced by strategic moves 
intentionally made by me to disrupt marginalizing discourse or practices. The field of equityfocused TA could benefit from additional study in this area. Specifically, research evaluating the extent to which the TA practitioners' social identities leveraged as mediating tools facilitate advancement in recipients' critical practice would further illuminate the utility of social identities as mediating tools. Furthermore, investigating the impact of TA practitioners' social identities on the provision of equity-focused TA could have significance relating to the recruitment of practitioners possessing minoritized social identities in the TA field, the extent to which practitioners possessing minoritized social identities experience microaggression and battle fatigue (Smith, 2004), and possible professional learning that TA practitioners could benefit from related to engaging in critical reflexive practice.

\section{Systemic change work}

Transformational work toward educational equity must be systemic; requiring efforts not only at multiple layers of the system - classroom, school, district, state, and national; but also in various aspects of schooling - policy, people, and practices (Kozleski \& Thorius, 2014). Integral to equity-focused TA is an understanding that transformative work is situated within critically examined contexts. Equity-focused TA engages educators in critical examination of power dynamics, ideologies, norms, and practices that maintain problematic status quo conditions throughout the system. As active participants in the TA activity system, TA practitioners should not be excluded from this critical self-examination.

TA practitioners are integral in the mediation of new learning among TA recipients. However, sustainability of any large scale change requires shared ownership and investment of the members within the organization or system (Coburn, 2003). Therefore, it is important that school improvement strategies to redress inequities co-constructed within the TA experience reflect the 
interests of the TA recipients first and foremost. As such, TA practitioners should be aware of their own power within the provision of TA; and take care not to impose their will on TA recipients. The goal of equity-focused TA is to assist school organizations in surfacing inequitable practices and to support their critical inquiry into systemic factors sustaining the inequities. The collaborative nature of the TA relationship necessitates continuous critical reflexivity on part of the TA practitioner in terms of one's positionality, and is an essential part of the TA relationship.

\section{Conclusion}

Equity-focused TA targets the dismantling of oppressive systems that marginalize minoritized students and create barriers to achieving educational equity for all students. The TA practitioner can be instrumental in this process by not only exhibiting the technical skills related to effective consultation or professional development but also by leveraging their own social identities and positionality within the provision of TA. TA practitioners who possess minoritized social identities can use their embodied identities to interrupt marginalizing ideologies exhibited by educators in ways that provoke introspection and cultivate critical consciousness. In this article I examined how my social identities, intersectional education history, and lived experiences serve as instruments of tensions, affecting interactions within the TA activity system. In doing so, I explored three situated strategic moves I employ to disrupt marginalizing practices among the educators with whom I have worked. These re (mediating) moves have proven to be impactful in my practice and have contributed to transformative change towards educational equity.

\section{Disclosure statement}

No potential conflict of interests was reported by the author. 


\section{Notes on contributor}

Seena M. Skelton (http://orcid.org/0000-0002-7402-1483) is Director of Operations of the Midwest and Plains Equity Assistance Center at Indiana University-Purdue University Indianapolis, one of four federally-funded centers providing technical assistance and training in the areas of race, sex, national origin, and religion for public school systems to promote equitable education opportunities. Seena has more than 20 years of experience working with education practitioners and scholars to support transformational change in school systems, with particular emphasis on creating inclusive and equitable learning conditions for historically marginalized youth. 


\section{References}

Algozzine, B., Forgnone, C., Mercer, C., \& Trifiletti, J. (1979). Toward defining discrepancies for specific learning disabilities: An analysis and alternatives. Learning Disability Quarterly, 2(4), 25-31. doi:10.2307/1510822

Allen, R. L. (1999, April). The hidden curriculum of whiteness: White teachers, white territory, and white community. Paper presented at the Annual Meeting of the American Educational Research Association, Montreal, Canada.

Annamma, S. A., Connor, D. J., \& Ferri, B. A., (2016). Dis/ability critical race studies (DisCrit): Theorizing at the intersections of race and dis/ability. In D. J. Connor, B. A. Ferri, \& S. A. Annamma (Eds.), DisCrit: Disability studies and critical race theory in education (pp. 9-32). New York, NY: Teachers College Press.

Artiles, A. J. (2011). Toward an interdisciplinary understanding of educational equity and difference: The case of the racialization of ability. Educational Researcher, 40, 431-445. doi:10.3102/0013189X11429391

Artiles, A. (2013). Untangling the racialization of disabilities: An intersectionality critique across disability models. Du Bois Review, 10(2), 329-347. doi:10.1017/S1742058X13000271

Artiles, A. J., \& Kozleski, E. B. (2016). Inclusive education's promises and trajectories: Critical notes about future research on a venerable idea. Education Policy Analysis Archives, 24(43), 43. doi:10.14507/epaa.24.1919,

Blake, E. (1967, November). A re-definition of educational problems occasioned by desegregation and Title IV of the Civil Rights Act of 1964. Paper presented at the National 
Conference on Equal Educational Opportunity in America's cities, U.S. Commission on Civil Rights, Washington DC.

Blustein, J. (2012). Philosophical and ethical issues in disability. Journal of Moral Philosophy, 9(4), 573-587. doi:10.1163/17455243-00904002

Bonilla-Silva, E. (2013). Racism without racists: Color-blind racism and the persistence of racial inequality in the United States (2nd ed.). Boulder, CO: Rowman \& Littlefield.

Boozer, M. A., Kruger, A. B., Wolkon, S. A., Haltiwanger, J. C., \& Loury, G. (1992). Race and school quality since Brown v. Board of Education, Brookings papers on economic activity. Microeconomics, 269, 338. Retrieved from https://www.brookings.edu/wpcontent/uploads/1992/01/1992_bpeamicro_boozer.pdf

Bradley, D., \& Fisher, S. F. (1998). The encyclopedia of civil rights in America. Armonk, NY: Sharpe.

Carey, R. L. (2013). A cultural analysis of the achievement gap discourse: Challenging the language and labels used in the work of school reform. Urban Education, 49(4), 440-468. doi:10.1177/0042085913507459

Chambers, T. V. (2009). The "recievement gap": School tracking policies and the fallacy of the“achievement gap". The Journal of Negro Education, 78 (4), 441-431.

Chen, K., Macey, E., Rogers, J., Simon, M., Skelton, S. M., \& Thorius, K. A. K. (2014). Engaging school systems as equity-oriented learning organizations. In Equity dispatch. Indianapolis, IN: Great Lakes Equity Center (GLEC). Retrieved from https://greatlakesequity.org/sites/default/files/20170103395_newsletter.pdf 
Cipriano-Walter, M. (2015). Falling off the track: How ability tracking leads to intra-school segregation. Thurgood Marshall Law Review, 41(25), 53. Retrieved from http://tmlawreview.org/assets/uploads/2016/07/2-CIPRIANO-WALTER-3.pdf

Coburn, C. E. (2003). Rethinking scale: Moving beyond numbers to deep and lasting change. Educational Researcher, 32(6), 3-12. doi:10.3102/0013189X032006003

Cole, M. M., \& Wertsch, J. (1996). Beyond the individual-social antinomy in discussions of Piaget and Vygotsky. Human Development, 39, 250-256. doi:10.1159/000278475

Crensaw, K., Ocen, P., \& Nanda, J. (2014). Black girls matter: Pushed out, overpoliced and underprotected. New York, NY: Center for Intersectionality and Social Policy African American Policy Forum. Retrieved from https://www.atlanticphilanthropies.org/wpcontent/uploads/2015/09/BlackGirlsMatter_Report.pdf

Crenshaw, K. (1989). Demarginalizing the intersection of race and sex: A Black feminist critique of antidiscrimination doctrine, feminist theory and antiracist politics. University of Chicago Legal Forum, 139, 139-167. Retrieved from https://chicagounbound-uchicagoedu.proxy.ulib.uits.iu.edu/cgi/viewcontent.cgi?article $=1052 \&$ context $=$ uclf

Darden, J., Rahbar, M., Jezierski, L., Li, M., \& Velie, E. (2010). The measurement of neighborhood socioeconomic characteristics and black and white residential segregation in metropolitan Detroit: Implications for the study of social disparities in Health. Annals of the Association of American Geographers, 100(1), 137-158. doi:10.1080/00045600903379042

Davis, L. J. (1995). Enforcing normalcy disability, deafness and the body. New York, NY: Verso. 
Davis, L. (2013). The disability studies reader. New York, NY: Routledge. ,

Delgado, R., \& Stefancic, J. (2000). Critical race theory: The cutting edge. Philadelphia, PA: Temple University Press.

DiAngelo, R. (2011). White fragility. International Journal of Critical Pedagogy, 3(3), 54-70. Retrieved from http://libjournal.uncg.edu/ijcp/article/view/249/116

DiAngelo, R. J. (2010). Why can't we all just be individuals? Countering the discourse of individualism in anti-racist education. (1). Retrieved from http://www.ulib.iupui.edu/cgibin/proxy.pl?url=https://search-ebscohostcom.proxy.ulib.uits.iu.edu/login.aspx?direct=true $\& \mathrm{db}=$ edssch $\& A N=$ edssch.qt5fm $4 \mathrm{~h} 8 \mathrm{wm} \&$ site $=$ eds-live

Donovan, M. S., \& Cross, C. T. (2002). Minority students in special and gifted education. Washington, DC: National Research Council.

Dudley-Marling, C., \& Burns, M. B. (2014). Two perspectives on inclusion in the United States. Global Education Review, 1(1), 14-31. Retrieved from https://ger.mercy.edu/index.php/ger/article/view/10

Duncan-Andrade, J. (2007). Gangstas, wankstas, and ridas: Defining, developing, and supporting effective teachers in urban schools. International Journal of Qualitative Studies in Education, $20,617-638$.

Education for All Handicapped Children Act of 1975 [EHA]. (1975). Retrieved from https://www.gpo.gov/fdsys/pkg/STATUTE-89/pdf/STATUTE-89-Pg773.pdf 
Engeström, Y. (1999). Activity theory and individual and social transformation. In Y.

Engeström, R. Miettinen, \& R.-L. Punamäki (Eds.), Perspectives on activity theory (pp. 19-38).

New York, NY: Cambridge University Press. doi:10.1017/CBO9780511812774.003

Engeström, Y. (2011, June). Conference: Cre8ing a learning world: Proceedings of the 8th International Conference for the Learning Sciences, Utrecht, The Netherlands, Vol. 1, June 23$28,2008$.

Fergus, E. (2017). Solving disproportionality and achieving equity: A leader's guide to using data to change hearts and minds. Thousand Oaks, CA: Corwin.

Ferri, B. A., \& Connor, D. J. (2005). In the shadow of Brown. Remedial \& Special Education, 26(2), 93-100. doi:10.1177/07419325050260020401

Fierros, E. G., \& Conroy, J. W. (2002). Double jeopardy: An exploration of restrictiveness and race in special education. In D. J. Losen \& G. Orfield (Eds.), Racial inequity in special education (pp. 39-70). Cambridge, MA: Harvard Education Press.

Ford, D., \& Grantham, T. (2003). Providing access to culturally diverse gifted students: Deficit to dynamic thinking. Theory into Practice, 42(3), 217-225. doi:10.1207/s15430421tip4203_8

Ford, D. Y., \& Harmon, D. A. (2011). Equity and excellence: Providing access to gifted education for culturally diverse students. Journal of Secondary Gifted Education, 12(3), 141147. doi:10.4219/jsge-2001-663

Gass, R. (2010). What is transformational change? In R. Gass (Ed.), Framing deep change: Essays on transformative social change (pp. 12-14). Berkeley, CA: Third Way Press. 
Hernández-Saca, D. (2017). Reframing the master narratives of dis/ability at my intersections: An outline of an educational equity research agenda. Researchgate. Retrieved from https://goo.gl/2Qja8D

Huber, J. J., Artiles, A. J., \& Hernández-Saca, D. I. (2012). Special education and students of color. In J. A. Banks (Ed.), Encyclopedia of diversity in education (2067-2071). Thousand Oaks, CA: SAGE. Retrieved from http://www.sageereference.com/view/diversityineducation/n649.xml Individuals with Disability Education Act Amendments of 1997 [IDEA]. (1997). Retrieved from https://www.congress.gov/105/plaws/publ17/PLAW-105publ17.pdf

Johnson, A. (2001). Privilege, power, and difference. New York, NY: McGraw-Hill Education.

Karnes, F. A., Shaunessy, E., \& Bisland, A. (2004). Gifted students with disabilities are we finding them? Gifted Child Today, 27(4), 16. doi:10.4219/gct-2004-148

Kavale, K. A., \& Forness, S. R. (2000). What definitions of learning disability say and don't say: A critical analysis. Journal of Learning Disabilities, 33(3), 239-256.

doi:10.1177/002221940003300303

Keisch, D. M., \& Scott, T. (2015). U.S. education reform and the maintenance of white supremacy through structural violence. Landscapes of Violence, 3(3), 1-46.

Kozleski, E. B., \& Artiles, A. J. (2012). Technical assistance as inquiry: Using activity theory methods to engage equity in educational practice communities. Academia. Retrieved from https://goo.gl/6C3XMR 
Kozleski, E. B., \& Thorius, K. A. K. (2013). Ability, equity, and culture: Sustaining inclusive urban education reform. New York, NY: Teachers College Press.

Kozleski, E. B., \& Waitoller, F. R. (2010). Teacher learning for inclusive education:

Understanding teaching as a cultural and political practice. International Journal for Inclusive Education, 14(7), 655-666. doi:10.1080/13603111003778379

Ladson-Billings, G. (1998). Just what is critical race theory and what's it doing in a nice field like education? International Journal of Qualitative Studies in Education, 11(1), 7-24. doi:10.1080/095183998236863 [Taylor \& Francis Online]

Ladson-Billings, G. (2006). From the achievement gap to the education debt: Understanding achievement in U.S. schools. Educational Researcher, 35(7), 3-12. Retrieved from http://www.jstor.org.proxy.ulib.uits.iu.edu/stable/3876731

LoBianco, A. F., \& Sheppard-Jones, K. (2007). Perceptions of disability as related to medical and social factors. Journal of Applied Social Psychology, 37(1), 1-13.

Losen, D. J., \& Welner, K. G. (2001). Disabling discrimination in our public schools: Comprehensive legal challenges to inappropriate and inadequate special education. Harvard Civil Rights-Civil Liberties Law Review, 36(2), 411-460.

Love, B. J. (2004). Brown plus 50 counter-storytelling: A critical race theory analysis of the “majoritarian achievement gap" story. Equity \& Excellence in Education, 37, 227-246.

Manzitti, E. T., Boratynski, F., \& Rader, B. T. (1976). An evaluation of mainstreaming in vocational education programs in the state of Michigan. ERIC Michigan State University. Retrieved from https://files.eric.ed.gov/fulltext/ED132767.pdf 
McKenzie, K. B., \& Scheurich, J. J. (2004). Equity traps: A useful construct for preparing principals to lead schools that are successful with racially diverse students. Educational Administration Quarterly, 40(5), 601-632. doi:10.1177/0013161X04268839

McRuer, R. (2006). Crip theory: Cultural signs of queerness and disability. New York, NY: New York University Press.

Meinke, S. (2011). "Milliken v Bradley: The northern battle for desegregation". Michigan Bar Journal. Retrieved from https://www.michbar.org/file/journal/pdf/pdf4article1911.pdf.

Michigan State Board of Education. (1987, July). Revised administrative rules for special education and rules for school social worker and school psychological services. Lansing, MI: Michigan State Board of Education.

Midwest and Plains Equity Assistance Center. (2018). Region III equity assistance center partnership log. Indianapolis, IN: Midwest and Plains (MAP) Center.

Milliken, V. B. (1974). No. 73-434 Argued: February 27, 1974 Decided: July 25, 1974.

Morrison, D., Annamma, S. A., \& Jackson, D. D. (2017). Critical race spatial analysis: Mapping to understand and address educational inequity. Sterling, VA: Stylus.

Mulligan, E. M., \& Kozleski, E. B. (2009). A framework for culturally responsive cognitive coaching in schools. Retrieved from https://pll.asu.edu/p/content/framework-culturallyresponsive-cognitive-coaching-schools

Myer, O. M. (2018). Disabled identities and empowering language. The New Social Worker: The Social Worker Magazine. Retreived from http://www.socialworker.com/featurearticles/practice/disabled-identities-and-empowering-language/ 
Paris, D., \& Alim, H. S. (2014). What are we seeking to sustain through culturally sustaining pedagogy? A loving critique forward. Harvard Educational Review, 84(1), 85-100.

Perry, T., Steele, T. M., \& Hilliard, A. (2004). Young, gifted, and black: Promoting high achievement among African-American students. Boston, MA: Beacon Press.

Radd, S. I., \& Kramer, B. H. (2013). Dis eased: Critical consciousness in school leadership for social justice. Journal of School Leadership, 4(26), 580.

Russo, C. J., \& Ford, D. Y. (2015). Education for gifted students in the United States: An area in need of improvement. Education Law Journal, 16(3), 188-196.

Sedler, R. A. (1987). "The profound impact of Milliken v Bradley". Wayne State University Law School. Retrieved from http://bit.ly/2EC7Uc0

Skelton, S. M., Coomer, M. N., Jackson, R. G., Kyser, T. S., \& Thorius, K. A. K. (2017). Ensuring all students succeed, equity at the school level. Equity Dispatach. Midwest \& Plains Equity Assistance Center (MAP EAC).

Skiba, R., Artiles, A. J., Kozleski, E. B., Losen, D., \& Harry, B. (2016). Risks and consequences of over simplifying educational inequities: A response to Morgan et al. (2015). Educational Researcher, 45(3), 221-225. doi:10.3102/0013189X16644606, ,

Smith, W. A. (2004). Black faculty coping with racial battle fatigue: The campus racial climate in a post-civil rights era. In D. Cleveland (Ed.), A long way to go: Conversations about race by African American faculty and graduate students (pp. 171-190). New York, NY: Peter Lang.

Sullivan, A. L., Artiles, A., \& Hernandez-Saca, D. I. (2015). Addressing special education inequity through systemic change: Contributions of ecologically based organizational 
consultation. Journal of Educational and Psychological Consultation, 25(2-3), 129-147. doi:10.1080/10474412.2014.929969

Sullivan, A. L., \& Bal, A. (2013). Disproportionality in special education: Effects of individual and school variables on disability risk. Council for Exceptional Children, 79(4), 475-494. ,

Sutton, M., \& Levinson, B. (Eds). (2001). Policy as practice: Toward a comparative sociocultural analysis of educational policy. Westport, CT: Ablex Press.

Tan, P., \& Thorius, K. A. K. (2018). En/countering inclusive mathematics education: A case of professional learning. Mathematics Teacher Educator, 6(2), 52-67. Retrieved from http://www.jstor.org.proxy.ulib.uits.iu.edu/stable/10.5951/mathteaceduc.6.2.0052

Thorius, K. A. K. (2016). Stimulating tensions in special education teachers' figured world: An approach toward inclusive education. International Journal of Inclusive Education, 20(12), 1326-1343. doi:10.1080/13603116.2016.1168877

Thorius, K. A. K., Maxcy, B., \& Nguyen, T. S. (2015, September). Equity-focused technical assistance in the transition of United States public schools. Paper presentation at European Conference on Educational Research, Budapest, Hungary.

Thorius, K. A. K., \& Simon, M. (2014). Multidisciplinary collaboration to support struggling readers: Centering culture in concerns about process and outcomes. Journal of Educational and Psychological Consultation, 2(24), 165-182.

Thorius, K. A. K., Skelton, S. M., \& Warren, C. (2016). Midwest and Plains Equity Assistance Center. Civil Rights Training and Advisory Services. Equity Assistance Centers Programs CFDA, 84, 004D. 
Title IV of the Civil Rights Act of 1964: Desegregation of public education.

Trohanis, T. A. (2014, June). Projects at the Frank Porter Graham Child Development Institute. Guiding Principles for Effective Technical Assistance. Retrieved from http://ectacenter.org/ pdfs/trohanis/trohanis_guiding_principles.pdf

U.S. Census Bureau. (1970). Census of population and housing-1970-general demographic trends. Final Report. Retrieved from https://www2.census.gov/prod2/decennial/documents/42189394v1-26_TOC.pdf U.S. Department of Education. (2017). Website title home article title federal role in education date. Retrieved from January 15, 2011, from https://www2.ed.gov/about/overview/fed/role.html Published May 25. https://www2.ed.gov/programs/equitycenters/index.html

Valencia, R. R. (2015). Students of color and the achievement gap: Systemic challenges, Systemic Transformation. New York, NY: Routledge

Vygotsky, L. S. (1978). Mind in society. Cambridge, MA: Harvard University Press.

Waitoller, F., \& Kozleski, E. B. (2013). Understanding and dismantling barriers for partnerships for inclusive education: A cultural historical activity theory perspective. International Journal of Whole Schooling, 9(1), 23-42.

Waitoller, F., \& Thorius, K. A. K. (2016). Cross-pollinating culturally sustaining pedagogy and universal design for learning: Toward an inclusive pedagogy that accounts for dis/ability. Harvard Educational Review, 86(3), 366-389. 
Watts, I., \& Erevelles, N. (2004). These deadly times: Reconceptualizing school violence by using critical race theory and disability studies. American Educational Research Journal, 41(2), 271-299. Retrieved from http://www.jstor.org.proxy.ulib.uits.iu.edu/stable/3699367 , ,

Wright, B. L., Ford, D. Y., \& Young, J. L. (2017). Ignorance or indifference? Seeking excellence and equity for under-represented students of color in gifted education. Global Education Review, $4(1), 45-60$.

Yun, J., \& Reardon, S. F. (2005). In J. Scott (Ed.), What the evidence says in school choice and diversity. New York, NY: Teacher College Press.

Zardoya, I. (2017). What school leaders must learn about equity: ESSA offers an opportunity to improve cultural competency. Retrieved from http://www.edweek.org.proxy.ulib.uits.iu.edu/ew/articles/2017/02/15/how-essa-can-teachschool-leaders-about.html 